\title{
UJI AKTIVITAS ANTIOKSIDAN EKSTRAK BUAH KLUWIH (Artocarpus communis)
}

\section{Antioxidant Activity Test of Artocarpus Camansi (Artocarpus Communis) Fruit Extracts}

\author{
*Mohammad Arif, Nurdin Rahman dan Supriadi \\ Pendidikan Kimia/FKIP - Universitas Tadulako, Palu - Indonesia 94118 \\ Received 19 March 2018, Revised 18 April 2018, Accepted 14 May 2018
}

\begin{abstract}
This studv aimed to determine antioxidant activitv of artocarpus camansi fruit extracts from Sigi, Central Sulawesi. This studv was conducted bv maceration extraction technique, and 2,2-diphenvl-1-picrvlhvdrazvl (DPPH) as the source of free radicals, and vitamin $C$ as a positive control. UV-Vis spectrophotometer was used for measuring the absorbance of artocarpus camansi fruit extracts. artocarpus camansi fruit powder was extracted bv maceration using ethanol. Various concentrations of artocarpus camansi fruit extracts used were 20, 40,60 , and $80 \mathrm{mg} / \mathrm{L}$. The results showed that the $I C_{50}$ value for artocarpus camansi (artocarpus communis) fruit extract was $88.715 \mathrm{mg} / \mathrm{L}$, whereas the $I C_{50}$ value for vitamin $C$ was $37.153 \mathrm{mg} / \mathrm{L}$. Artocarpus camansi (artocarpus communis) fruit extracts are powerful antioxidants category based on $I C_{50}$ value. The optimum percentage antioxidant activity of artocarpus camansi fruit extracts to inhibit free radical amounted to by $50.65 \%$
\end{abstract}

Keywords: Antioxidant, artocarpus camansi, vitamin $\mathrm{C} \mathrm{IC}_{50}$, DPPH, kluwih

\section{Pendahuluan}

Indonesia merupakan negara yang memiliki kekayaan alam yang melimpah salah satunya adalah rempah ataupun bahan makanan, hanya saja pemanfaatan bahan makanan yang diperoleh dari alam belum optimal. Perlu dilakukan kajian yang lebih lanjut tentang manfaat pada setiap bahan makanan yang diolah masyarakat sebagai kebutuhan sehari hari untuk dapat tetap memperoleh gizi dari makanan, kurangnya pengetahuan masyarakat tentang kandungan gizi pada bahan makanan yang diolah menjadi makanan yang dikonsumsi sehari-hari membuat pemanfaatan bahan makanan yang disediakan alam belum optimal, seperti buah kluwih. Buah kluwih (Artocarpus communis) merupakan tanaman yang bergetah, hampir semua bagian tanaman ini mengeluarkan getah baik bunga, daun, ranting batang dan akar (Pitojo, 2005).

Hampir seluruh bagian tanaman kluwih memiliki manfaat, getah kluwih dapat dimanfaatkan untuk dijadikan sebagai perangkap burung, bunga kluwih yang telah kering dapat dimanfaatkan sebagai upet atau sebagai pengusir nyamuk ketika dibakar, daun kluwih berguna sebagai pakan ternak, kayu kluwih dapat berguna sebagai bahan pembuatan perangkat rumah tangga, buah kluwih yang muda dapat dijadikan sebagai bahan makanan seperti sayur sedangkan biji kluwih juga dapat dimanfaatkan sebagai bahan pangan (Pitojo, 2005).

*Correpondence

Mohammad Arif

Program Studi Pendidikan Kimia, Fakultas Keguruan dan Ilmu Pendidikan, Universitas Tadulako

e-mail:marifmarif59@gmail.com

Published by Universitas Tadulako2018
Buah kluwih muda mengandung vitamin $\mathrm{C}$ sebesar $19 \mathrm{mg} / 100$ gram, dimana vitamin C merupakan golongan antioksidan sekunder yang berfungsi mencegah reaksi radikal atau reaksi oksidasi serta mencegah terjadinya reaksi berantai, selain vitamin $\mathrm{C}$ buah kluwih memiliki kandungan yang lain seperti energi $111 \mathrm{kkal}$, protein 1,5 gram, lemak 0,3 gram, karbohidrat 27,2 gram, kalsium $28 \mathrm{mg}$, phosporus $32 \mathrm{mg}$, besi $0,9 \mathrm{mg}$, vitamin A 20 SI dan vitamin B 0,10 mg (Pitojo, 2005).

Kehidupan sehari-hari manusia tidak lepas dari bahaya senyawa radikal bebas yang berasal dari asap kendaraan, paparan sinar matahari yang berlebihan, makanan yang digoreng, polusi udara dan obat obatan tertentu (Wijaya, 1996). Sebagai molekul yang tidak stabil radikal bebas memiliki satu atau lebih elektron yang tidak berpasangan sehingga elektron tersebut bersifat reaktif dalam mencari pasangan elektronnya apabila telah terbentuk dalam tubuh maka radikal bebas akan terus bertambah dan akan merusak sel sel dalam tubuh (Saurisari, 2006). Radikal bebas merupakan senyawa yang menginduksikan penyakit kanker dan juga penuaan dini yang disebabkan oksidasi yang mana menyebabkan kerusakan jaringan sehingga diperlukan senyawa yang bersifat antioksidan untuk menghambat aktivitas radikal bebas (Kikuzaki \& Nakatami, 2002).

Antioksidan merupakan senyawa yang dapat meredam reaksi oksidasi, dengan menyumbangkan satu elektronnya pada radikal bebas sehingga dapat mengikat radikal bebas. Akibatnya kerusakan jaringan dapat dihambat (Winarsi, 2007). Menurut Trilaksani (2003) berdasarkan sumbernya antioksidan dapat dibagi menjadi dua, yaitu antioksidan alami dan antioksidan buatan/sintesis. Buah, biji, daun, akar, maupun batang tanaman mengandung antioksidan alami yang mempunyai manfaat bagi kesehatan (Prakash, 2001). Turunan 
fenol, kumarin, hidroksi sinamat, tokoferol, difenol, flavonoid, kathekin, dan asam askorbat merupakan golongan antioksidan alami. Golongan antioksidan sintesis antara lain adalah butyl hidroksilanisol, butyl hidroksitoluen, propil galat, etoksiquin (Cahyadi, 2006).

Akhir-akhir ini senyawa antioksidan alami banyak dikaji oleh berbagai penelitian sebagai komponen pangan fungsional dan suplemen makanan. Antioksidan berfungsi melindungi tubuh dalam berbagai penyakit yang disebabkan oleh radikal bebas seperti kanker dan jantung koroner (Andayani, dkk., 2008)

Beberapa penelitian membuktikan bahwa pada tumbuhan dan buah buahan dapat melindungi tubuh dari bahaya radikal bebas. $\mathrm{Hal}$ ini dikarenakan adanya kandungan antioksidan dalam tumbuhan dan buah buahan tersebut. Antioksidan tersebar secara alami pada berbagai bagian tanaman yaitu pada daun, batang, buah, akar, ranting, kulit dan biji tanaman (Samosir, 2010).

Tulisan ini dimaksudkan untuk menentukkan nilai $I C_{50}$ dari ekstrak buah kluwih yang berfungsi sebagai antioksidan yang dapat menangkal radikal bebas.

\section{Metode}

\section{Alat dan bahan}

Peralatan yang digunakan adalah Spectrophotometer UV-Vis T80+ PG Instruments Ltd, blender, labu ukur, kuvet, neraca analitik Adam pgw 254 (england), pipet tetes, alumunium foil, oven MMM - Medcenter, ayakan, pisau, loyang, labu ukur, gelas ukur, gelas kimia, batang pengaduk, rotary evaporator (EYELA SB-1100) dan corong.

Bahan yang digunakan dalam penelitian ini yaitu buah kluwih (artocarpus communis), etanol p.a. (J.T. BAKER), vitamin C (Merck) dan padatan DPPH (2,2-difenil-1-pichrylhydrazyl) (Aldrich)

\section{Prosedur kerja}

Penelitian ini menggunakan prosedur $\mathrm{Uji}$ Aktivitas Antioksidan dari Nur, (2015). Sampel buah kluwih dicuci dengan air mengalir kemudian pada buah kluwih diambil daging buahnya lalu dipotong kecil kecil, dan dioven pada suhu $48{ }^{\circ} \mathrm{C}$ selama 1 x 24 jam. Selanjutnya buah kluwih yang sudah kering dihaluskan menggunakan blender kemudian sampel yang sudah halus diekstraksi menggunakan etanol.

50 gram kluwih yang sudah halus dimaserasi dengan menggunakan etanol absolute $500 \mathrm{~mL}$ selama $3 \times 24$ jam sambil sesekali diaduk setelah 3 $\times 24$ jam ekstrak disaring, residu yang diperoleh dimaserasi kembali denggan cara yang sama. Setelah itu hasil ekstrak disaring kemudian filtrat yang diperoleh dipekatkan dengan menggunakan rotary evaporator pada suhu $40{ }^{\circ} \mathrm{C}$.

2,5 mg DPPH dilarutkan menggunakan etanol pada labu ukur $25 \mathrm{~mL}$ kemudian dicukupkan volumenya dengan etanol hingga tanda batas. 2,5 mL larutan DPPH diambil, kemudian dimasukkan ke dalam labu ukur $25 \mathrm{~mL}$, lalu dicukupkan volumenya dengan etanol hingga tanda batas setelah itu larutan diinkubasi selama 30 menit.

Ekstrak kluwih $25 \mathrm{mg}$ dilarutkan dalam labu ukur $25 \mathrm{~mL}$ dengan etanol yang mana berat jenis etanol diasumsikan sama dengan 1 , kemudian volumenya dicukupkan dengan etanol hingga tanda batas. $25 \mathrm{mg}$ vitamin $\mathrm{C}$ diambil kemudian ditambahkan aquades secukupnya lalu dicukupkan volumenya hingga $25 \mathrm{~mL}$ dengan etanol.

Larutan induk diambil masing masing 0,5, 1 , 1,5 dan 2 mL lalu dimasukkan ke dalam masing masing labu ukur $25 \mathrm{~mL}$ setelah itu masing masing dari larutan ditambahkan 2,5 $\mathrm{mL}$ DPPH kemudian dicukupkan volumenya dengan etanol sampai garis tanda batas. Larutan induk diambil masing masing sebanyak $0,5,1,1,5$ dan $2 \mathrm{~mL}$ lalu dimasukkan ke dalam masing masing labu ukur 25 $\mathrm{mL}$ setelah itu masing-masing dari larutan ditambahkan 2,5 $\mathrm{mL}$ DPPH kemudian dicukupkan volumenya dengan etanol sampai garis tanda batas. Larutan blanko dimasukkan ke dalam kuvet kemudian diukur absorbansinya pada panjang gelombang $517 \mathrm{~nm}$ dengan alat spektrofotometer UV-Vis.

Masing masing larutan uji dengan konsentrasi $(20,40,60,80) \mathrm{mg} / \mathrm{L}$ dimasukkan ke dalam kuvet kemudian diukur absorbansinya pada panjang gelombang yang sama dengan alat spektrofotometer UV-Vis.

Masing masing larutan pembanding dengan konsentrasi $(20,40,60,80) \mathrm{mg} / \mathrm{L}$ dimasukkan ke dalam kuvet kemudian diukur absorbansinya pada panjang gelombang $517 \mathrm{~nm}$ dengan alat spektrofotometer UV-Vis.

Untuk menetukan nilai $I C_{50}$ menggunakan rumus: $I C_{50}=\mathrm{A} \log \mathrm{x}$. Nilai $I C_{50}$ diperoleh dari beberapa tahapan yaitu menghitung nilai log konsentrasi dan nilai probit untuk masing-masing persentase aktivitas penghambat radikal bebas DPPH. Selanjutnya menghubungkan kedua data dari perhitungan yang diperoleh dalam 1 grafik utuh, dimana nilai log konsentrasi dijadikan sebagai sumbu $\mathrm{x}$ dan nilai probit digunakan sebagai sumbu y (Nur, 2015).

\section{Hasil dan Pembahasan}

\section{Ekstraksi buah lluwih menggunakan etanol}

Hasil ekstraksi 50 gram sampel buah kluwih menggunakan $500 \mathrm{~mL}$ etanol absolut diperoleh massa ekstrak sebanyak 13,51 gram.

\section{Hasil pengukuran absorbansi}

Hasil pengukuran absorbansi sampel dan pembanding (vitamin C) yang sudah ditambahkan larutan DPPH dengan berbagai variasi konsentrasi disajikan pada Tabel 1 .

\section{Ekstraksi buab kluwih menggunakan etanol absolut}

Ekstraksi adalah suatu proses penarikan zat pokok yang diinginkan dari bahan mentah obat atau simplisia dengan menggunakan pelarut yang 
dipilih dimana zat yang diinginkan larut (Ansel, 1989). Metode pemisahan ini bekerja berdasarkan prinsip kelarutan like dissolve like, yaitu pelarut polar akan melarutkan zat polar, dan sebaliknya (Khopkar, 2003).

Tabel 1. Hasil pengukuran absorbansi ekstrak buah kluwih dan vitamin $\mathrm{C}$

\begin{tabular}{cccc}
\hline & & \multicolumn{2}{c}{ Absorbansi (A) } \\
\cline { 3 - 4 } No & Konsentrasi (mg/L) & $\begin{array}{c}\text { Buah } \\
\text { kluwih }\end{array}$ & Vitamin C \\
\hline 1. & 20 & 0,581 & 0,324 \\
2. & 40 & 0,564 & 0,301 \\
3. & 60 & 0,393 & 0,224 \\
4. & 80 & 0,302 & 0,128 \\
\hline
\end{tabular}

Pada tahap awal yaitu menyiapkan sampel buah kluwih yang akan diekstrak dengan mencuci kluwih dengan air mengalir hal ini bertujuan untuk memisahkan kotoran kotoran yang masih menempel pada buah kluwih. Kemudian pada buah kluwih diambil daging buahnya lalu dipotong kecil kecil, hal ini bertujuan untuk memudahkan proses penggilingan, kemudian sampel dioven pada suhu $48^{\circ} \mathrm{C}$ selama $3 \times 24$ jam, proses ini bertujuan untuk menghilangkan kadar air serta meningkatkan daya tahan sampel agar tidak rusak, kerusakan sampel dapat disebabkan karena penjamuran. Pengeringan sampel tidak dilakukan dibawah sinar matahari karena dapat merusak kandungan kimia dari sampel (Hermansyah, dkk., 2015). Selanjutnya buah kluwih yang sudah kering dihaluskan dengan menggunakan blender tujuannya yaitu untuk memperoleh serbuk dan memperluas pori pori sampel sehingga mempermudah proses ekstraksi. Selanjutnya sampel yang sudah halus diayak kemudian ditimbang sebanyak 50 gram lalu diekstraksi menggunakan etanol sebanyak $500 \mathrm{~mL}$ selama $3 \times 24$ jam. Penggunaan etanol dalam proses ekstraksi dikarenakan etanol merupakan pelarut yang umum digunakan dan dapat mengekstrak hampir semua senyawa bahan alam yang bersifat polar dan non polar (Hermansyah, dkk., 2015).

Proses ekstraksi yang dilakukan yakni dengan metode perendaman (maserasi) metode maserasi merupakan metode penyaringan zat aktif dengan cara merendam serbuk simplisa dengan pelarut. Setelah $3 \times 24$ jam sampel disaring dengan menggunakan kertas saring untuk memperoleh filtrat, proses ekstraksi dilakukan sebanyak 2 kali hal ini bertujuan agar zat aktif lebih banyak terekstrak (Khopkar, 2003). Kemudian filtrat yang diperoleh dipekatkan dengan menggunakan rotary evaporator dan selanjutnya dilakukan pengujian aktivitas antioksidan.

\section{Uji aktivitas antioksidan buah kluwih}

Pada penelitian ini uji aktivitas antioksidan buah kluwih dengan mengunakan DPPH. DPPH dipilih karena cara ini sudah umum dilakukan untuk pengujian aktivitas antioksidan caranya mudah, sensitif dan cepat (Hermansyah, dkk.,
2015). Pengujian aktivitas menggunakan DPPH diukur dengan alat spektrofotometer UV-Vis .

Pengujian aktivitas antioksidan ekstrak buah kluwih dilakukan menggunakan variasi konsentrasi yaitu 20, 40, 60, dan $80 \mathrm{mg} / \mathrm{L}$ menggunakan spektrofotometer UV-Vis pada panjang gelombang $517 \mathrm{~nm}$ yaitu panjang gelombang maksimum dari DPPH. Senyawa DPPH sensitif terhadap beberapa basa Lewis dan jenis pelarut, serta oksigen. Penggunaan DPPH didasarkan pada penurunan absorbansi yang diakibatkan perubahan warna DPPH dari ungu menjadi kuning, perubahan ini disebabkan radikal pada DPPH ditangkap oleh atom $\mathrm{H}$ dari antioksidan yang dilepaskan dan membentuk DPPH-H stabil (Ozcelik, dkk., 2003).

Reaksi antara antioksidan dengan molekul DPPH dapat dilihat pada Gambar 1.

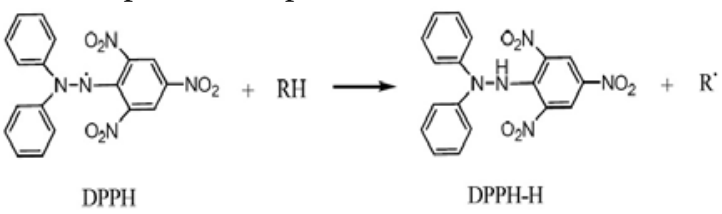

Gambar 1. Reaksi DPPH (2,2-difenil-1pikrilhidrazil) dengan antioksidan (Arindah, 2010).

Hasil pengukuran absorbansi ekstrak buah kluwih dapat dilihat pada Gambar 2.

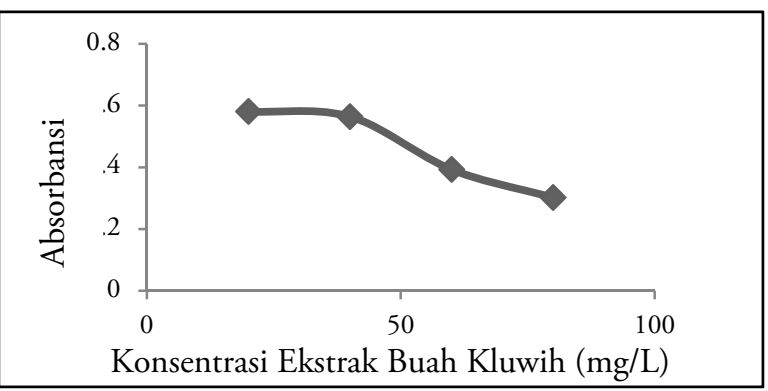

Gambar 2. Hubungan nilai absorbansi DPPH dengan konsentrasi ekstrak buah kluwih

Dari Gambar 2 dapat dilihat bahwa dengan meningkatnya konsentrasi ekstrak buah kluwih maka nilai absorbansi DPPH semakin kecil hal ini disebabkan oleh intensitas warna pada sampel dengan konsentrasi 20, 40, 60, dan $80 \mathrm{mg} / \mathrm{L}$ semakin berkurang sehingga cahaya lebih banyak diteruskan. Larutan DPPH yang awalnya berwarna ungu berubah menjadi sedikit lebih terang ketika ditambahkan ke dalam larutan ekstrak buah kluwih, hal ini disebabkan oleh senyawa antioksidan yang menangkap radikal bebas DPPH sehingga menjadi DPPH-H stabil.

Dari hasil pengukuran nilai absorbansi sampel maka diperoleh pula nilai persen penghambat dari ekstrak buah kluwih yang diperoleh dengan hasil perhitungan persentase penghambat radikal bebas yang disajikan pada Gambar 3.

Dari Gambar 3 dapat dilihat bahwa persen penghambat ekstrak buah kluwih semakin meningkat dengan meningkatnya konsentrasi sampel, pada konsentrasi $20 \mathrm{mg} / \mathrm{L}$ nilai persen penghambatnya $5,07 \%$, pada konsentrasi $40 \mathrm{mg} / \mathrm{L}$ nilai persen penghambatnya $7,84 \%$, untuk 
konsentrasi $60 \mathrm{mg} / \mathrm{L}$ nilai persen penghambat ekstrak buah kluwih meningkat signifikan yakni $35,78 \%$ dan untuk konsentrasi $80 \mathrm{mg} / \mathrm{L}$ nilai persen penghambat ekstrak buah kluwih adalah sebesar 50,65\%. Hasil perhitungan persentase penghambat radikal bebas tersebut sejalan dengan perubahan warna DPPH ketika ditambahkan ke dalam larutan ekstrak buah kluwih dimana warna yang paling terang menunjukkan persen penghambat radikal bebas lebih besar.

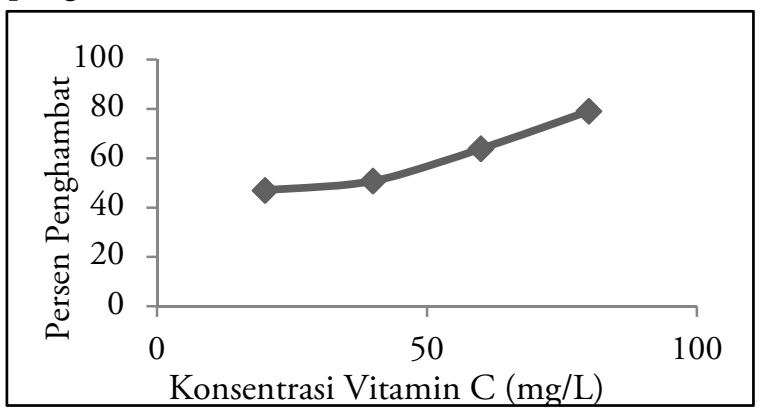

Gambar 3. Nilai Persen Penghambat Ekstrak Buah Kluwih

\section{Uji aktivitas antioksidan vitamin $C$}

Pengujian aktivitas antioksidan vitamin C dilakukan dengan cara yang sama pengujian ekstrak buah kluwih menggunakan pelarut etanol dan larutan DPPH sebagai kontrol negatif. Pada pengujian aktivitas antioksidan vitamin $\mathrm{C}$ ini digunakan konsentrasi yang sama pula dengan ekstrak buah kluwih yaitu 20, 40, 60 dan $80 \mathrm{mg} / \mathrm{L}$. Penggunaan konsentrasi yang sama dengan ekstrak buah kluwih bertujuan untuk melihat perbandingan aktivitas antioksidan ekstrak buah kluwih dengan vitamin $\mathrm{C}$ sebagai kontrol positif, dari penelitian yang dilakukan diperoleh nilai absorbansi untuk vitamin $\mathrm{C}$ pada Gambar 4 .

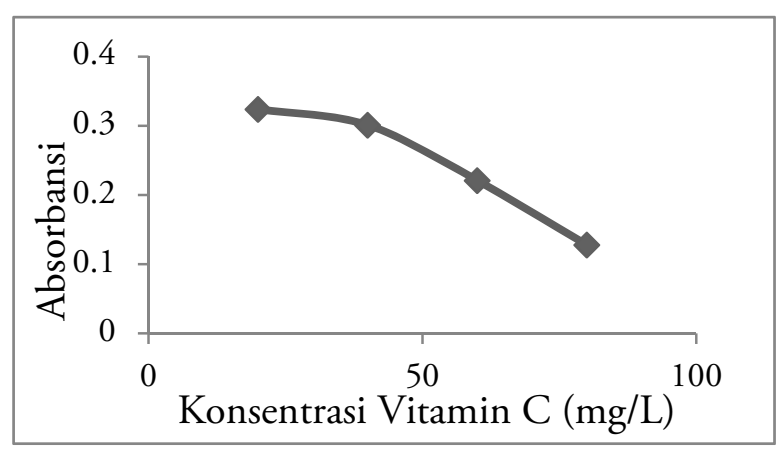

Gambar 4. Hubungan nilai absorbansi DPPH dengan konsentrasi

\section{Vitamin $C$}

Dari Gambar 4 dapat dilihat bahwa konsentrasi vitamin $C$ berbanding terbalik dengan nilai absorbansi DPPH dimana semakin tinggi konsentrasi vitamin $\mathrm{C}$ maka absorbansi DPPH semakin kecil, hal tersebut juga dikarenakan intensitas warna pada sampel dengan konsentrasi $20,40,60,80 \mathrm{mg} / \mathrm{L}$ semakin berkurang sehingga cahaya lebih banyak diteruskan.

Setelah diperoleh nilai absorbansi vitamin C untuk masing masing konsentrasi, langkah selanjutnya ialah menghitung nilai persen penghambat vitamin $\mathrm{C}$ dengan menggunakan nilai absorbansi yang telah diperoleh, pada Gambar 5 disajikan nilai persen penghambat vitamin C terhadap radikal bebas DPPH.

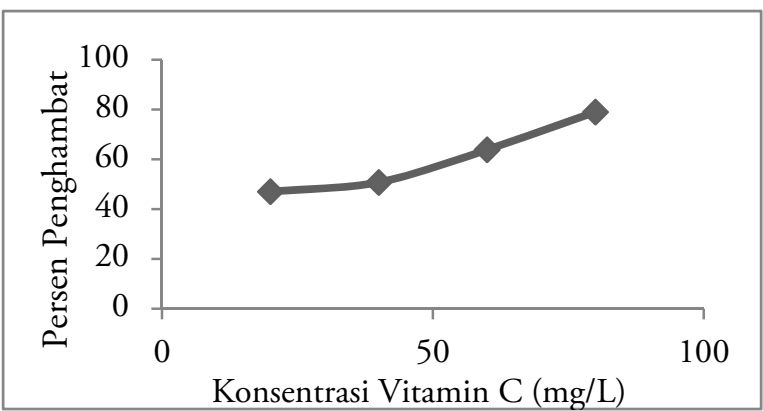

Gambar 5. Nilai Persen Penghambat Vitamin C

Pada Gambar 5 dapat dilihat bahwa persen penghambat vitamin $\mathrm{C}$ meningkat dengan meningkatnya konsentrasi yang artinya semakin tinggi konsentrasi vitamin $\mathrm{C}$ maka daya hambat vitamin $\mathrm{C}$ terhadap radikal bebas juga semakin besar. Hal ini disebabkan semakin tinggi konsentrasi vitamin $\mathrm{C}$ maka semakin banyak partikel partikel yang mengoksidasi DPPH.

\section{Perbandingan aktivitas penangkap radikal bebas} ekstrak buah kluwih dengan vitamin $C$

Pada hasil penelitian ini yaitu membandingkan aktivitas penangkap radikal bebas ekstrak buah kluwih dengan vitamin $\mathrm{C}$ sebagai kontrol positif yang dapat ditinjau dari persentase penghambat radikal bebas kedua sampel yakni ekstrak buah kluwih dan vitamin C sebagai kontrol positifnya, dari data hasil penelitian menunjukkan persen penghambat vitamin $\mathrm{C}$ lebih besar dibandingkan dengan persen penghambat ekstrak buah kluwih. Persen penghambat yang menjadi tujuan utama penelitian menunjukkan hasil yang lebih kecil dibandingkan dengan vitamin $C$ sebagai kontrol positifnya. Perbandingan persentase penghambat radikal bebas ekstrak buah kluwih dan vitamin $\mathrm{C}$ dapat dilihat pada Gambar 6.

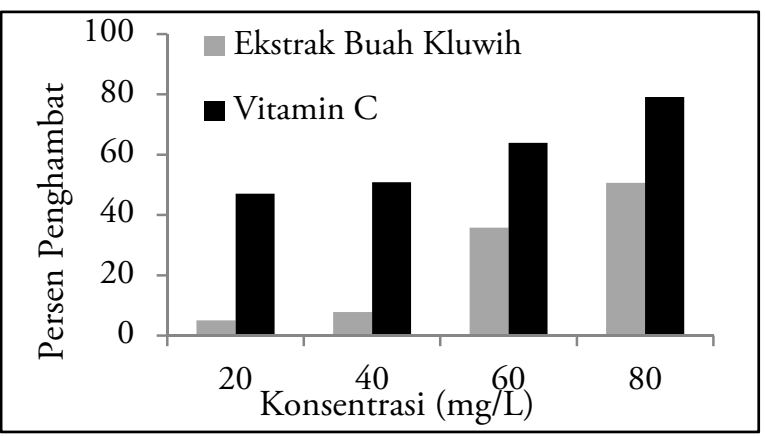

Gambar 6. Perbandingan persentase penghambat radikal bebas ekstrak buah kluwih dan vitamin $\mathrm{C}$

Dari gambar Gambar 6 dapat dilihat bahwa presentase penghambat radikal bebas ekstrak buah kluwih lebih kecil dibandingkan vitamin $\mathrm{C}$ dimana pada konsentrasi $20 \mathrm{mg} / \mathrm{L}-60 \mathrm{mg} / \mathrm{L}$ terlihat persen penghambat radikal bebas ekstrak buah kluwih berbeda jauh dengan vitamin $\mathrm{C}$, namun pada konsentrasi $80 \mathrm{mg} / \mathrm{L}$ perbedaan presentase penghambat radikal bebas ekstrak buah kluwih 
tidak berbeda signifikan yaitu 50,65\% untuk ekstrak buah kluwih dan 79,08\% untuk vitamin C dari data tersebut dapat dikatakan bahwa daya antioksidan ekstrak buah kluwih memiliki presentase yang baik pada konsentrasi $80 \mathrm{mg} / \mathrm{L}$ dan baik sebagai antioksidan alami.

\section{Perhitungan nilai $I_{50}$}

Pada penelitian ini yakni pengujian aktivitas antioksidan dari ekstrak buah kluwih menggunakan DPPH dan menggunakan interpretasi parameter $I C_{50}$ (inhibition concentration). $I C_{50}$ merupakan konsentrasi substrat atau sampel yang akan menyebabkan reduksi terhadap aktivitas DPPH (2,2-difenil-1pikrilhirazil) sebesar 50\% (Molyneux, 2004). Semakin kecil nilai $I C_{50}$ berarti semakin tinggi aktivitas antioksidan.

Untuk memperoleh nilai $I C_{50}$ digunakan beberapa tahapan yaitu menghitung nilai log konsentrasi dan nilai probit untuk masing masing presentase aktivitas penghambat radikal bebas dalam hal ini radikal bebas yang digunakan adalah DPPH (2,2-difenil,-1-pikrilhidrazil). Kemudian selanjutnya menghubungkan pada satu grafik utuh dimana nilai log konsentrasi dijadikan sebagai sumbu $\mathrm{X}$ dan nilai probit digunakan sebagai sumbu Y (Nur, 2015). Nilai $I C_{50}$ untuk ekstrak buah kluwih dan vitamin $\mathrm{C}$ dapat dilihat pada Gambar 7 dan 8 berikut.

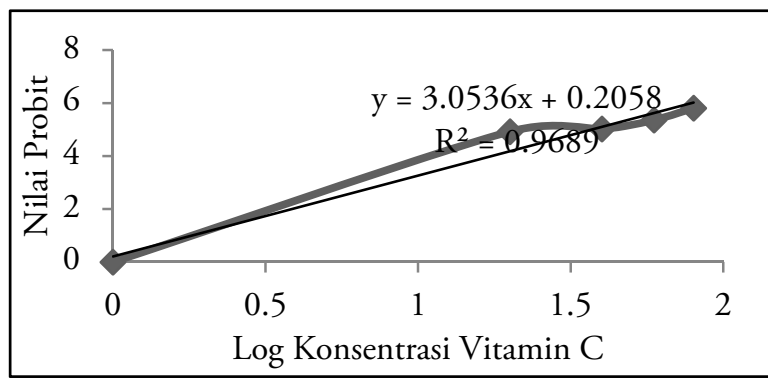

Gambar 7. Hubungan nilai probit dan log konsentrasi ekstrak buah kluwih

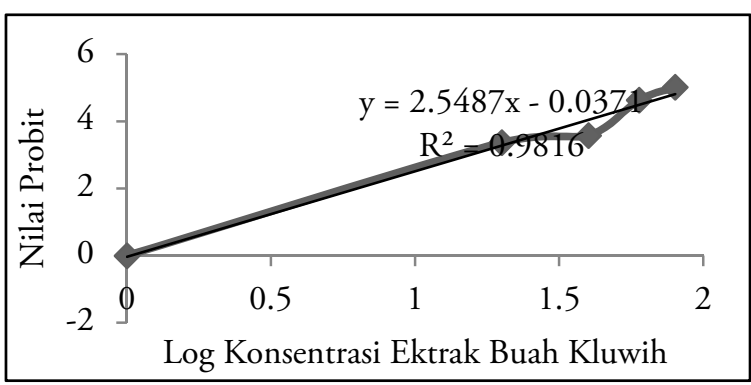

Gambar 8. Hubungan nilai probit dan log konsentrasi vitamin $\mathrm{C}$

Berdasarkan Gambar 7 dan 8 diperoleh persamaan regresi linear $y=2,548 x-0,037$ untuk ekstrak buah kluwih dan $y=3,053 x+0,205$ untuk vitamin C (kontrol positif) kemudian diperoleh pula nilai $r$ untuk masing masing esktrak buah kluwih (sampel) dan vitamin C (kontrol positif) berturut turut adalah 0,981 dan 0,968 berdasarkan nilai $\mathrm{r}$ yang diperoleh nilai probit ekstrak buah kluwih lebih baik dibandingkan nilai probit vitamin C. Berdasarkan Gambar 7 dan 8 data hasil penelitian dapat dikatakan sangat baik karena memiliki nilai $r$ mendekati 1 adapun yang mempegaruhi kurang baiknya data hasil penelitian yang memiliki nilai $\mathrm{r}$ tidak mendekati 1 adalah (Day, 1999): Kurang baiknya pembuatan deret konsentrasi larutan yang digunakan; Instrumen (Spektrofotometer UV-Vis yang tidak dikalibrasi secara benar) dan pengotor dalam kuvet yang digunakan sebagai tempat awal larutan.

Berdasarkan persamaan regresi linear, nilai $\mathrm{x}$ pada persamaan garis adalah nilai $I C_{50}$ untuk ekstrak buah kluwih dan vitamin $\mathrm{C}$, nilai $\mathrm{A} \log \mathrm{x}$ dari perhitungan adalah nilai $I C_{50}$ yang didapatkan dari angka perhitungan akhir. Dimana untuk ekstrak buah kluwih nilai $I C_{50} \quad 88,715 \mathrm{mg} / \mathrm{L}$ sedangkan untuk vitamin C $37,153 \mathrm{mg} / \mathrm{L}$.

Menurut Molyneux (2004) suatu senyawa dikatakan sebagai antioksidan sangat kuat jika nilai $I C_{50}$ kurang dari $50 \mathrm{mg} / \mathrm{L}$, kuat untuk $I C_{50}$ antara $50 \mathrm{mg} / \mathrm{L}-100 \mathrm{mg} / \mathrm{L}$, sedang jika $I C_{50}$ bernilai 101 $\mathrm{mg} / \mathrm{L}-150 \mathrm{mg} / \mathrm{L}$, dan lemah jika $I C_{50}$ bernilai 150 $\mathrm{mg} / \mathrm{L}-200 \mathrm{mg} / \mathrm{L}$. Berdasarkan dari tetapan nilai $I C_{50}$ tersebut maka dapat dikatakan bahwa ekstrak buah kluwih termasuk dalam golongan antioksidan kuat dikarenakan memiliki nilai $I C_{50} 88,715 \mathrm{mg} / \mathrm{L}$ yang berada dalam rentang $50 \mathrm{mg} / \mathrm{L}-100 \mathrm{mg} / \mathrm{L}$ sedangkan untuk vitamin $\mathrm{C}$ termasuk dalam golongan antioksidan yang sangat kuat, hal ini dikarenakan vitamin $\mathrm{C}$ memiliki nilai $I C_{50} 37,153$ $\mathrm{mg} / \mathrm{L}$ yang kurang dari $50 \mathrm{mg} / \mathrm{L}$.

Berdasarkan nilai $\mathrm{IC}_{50}$ yang diperoleh dapat dikatakan bahwa daya antioksidan ekstrak buah kluwih yang menjadi tujuan utama penelitian lebih kecil dibandingkan antioksidan vitamin $\mathrm{C}$ sebagai kontrol positifnya.

\section{Kesimpulan}

Persentase aktivitas penghambat radikal bebas ekstrak buah kluwih optimum dalam menghambat radikal bebas 2,2-difenil-1-pikrilhidrazil sebesar 50,65\%. Ekstrak buah kluwih dapat digolongkan sebagai antioksidan alami yang kuat berdasarkan nilai $\mathrm{IC}_{50}$ yang diperoleh sebesar $88,715 \mathrm{mg} / \mathrm{L}$

\section{Ucapan Terima Kasih}

Penulis mengucapkan terima kasih kepada Laboratorium Agroteknologi Fakultas Pertanian Universitas Tadulako dan Laboratorium Kimia Fakultas Keguruan dan Ilmu Pendidikan Universitas Tadulako serta semua pihak yang telah membantu dalam pelaksanaan penelitian ini.

\section{Referensi}

Andayani, R. Y., Lisawati \& Maimunah. (2008). Penentuan aktivitas antioksidan kadar fenolat total dan likopen pada buah tomat (solanum lycopensicum l). Jurnal Farmasi, 13(1), 4-10.

Ansel, C. H. (1989). Pengantar bentuk sediaan farmasi. Jakarta: UI Press.

Arindah, D. (2010). Fraksinasi dan identifikasi golongan senyawa pada daging buah pepimo (solonium muricatum aiton) yang berpotensi 
sebagai antioksidan. Malang: Universitas Islam Negeri Maulana Malik Ibrahim.

Cahyadi, S. (2006). Analisis dan aspek kesehatan bahan tambahan pangan. Jakarta: PT Bumi Aksara.

Day, R. A. (1999). Analisis kimia kuantitatif. Edisi keenam. Jakarta: Erlangga.

Hermansyah, A., Harlia \& Zahra, T. A. (2015). Skrinning fitokimia dan uji aktivitas antioksidan ekstrak kulit batang laban. Jurnal Kimia Khatulistiwa, 4(2), 67-71.

Khopkar, S. M. (2003). Konsep dasar kimia analitik Jakarta: UI Press.

Kikukazi, H. \& Nakatami, N. (2002). Antioxidants properties of ferulic acid and it's related compound. Journal Agriculture Food Chemistry, 50, 2161-2168.

Molyneux, P. (2004). The use of the stable free radical diphenylpicrylhydrazyl (DPPH) for estimating antioxidant activity. Journal Science Technology, 26(2), 211-219.

Nur, K. (2015). Uji aktivitas antioksidan ekstrak daun palado. (Skripsi), Palu: Universitas Tadulako.

Ozcelik, B., Lee, J. H. \& Min, D. B. (2003). Effect of light oxygent and $\mathrm{pH}$ on the absorbance of 2,2-diphenyl-1-picrylhidrazyl. Journal Food Science, 68, 487-490.
Pitojo, S. (2005). Seri budidaya kluwih. Yogyakarta: Kanisius.

Prakash, A. (2001). Antioxidant activity. Medallion Laboratories Analytical Progress, 19(2), 1-4.

Samosir, A. P. (2010). Uji aktivitas antioksidan dan total flavonoid pada ekstrak etanol pinang yaki (areca vestiaria). Skripsi, Manado: Universitas Sam Ratulangi.

Saurisari, R. (2006). Mengenal dan menangkal radikal bebas. Jurnal Sains dan Teknologi, 2(2), 183-187.

Trilaksani, W. (2003). Antioksidan: Jenis sumber, mekanisme kerja dan peran terhadap kesehatan. Bogor: Institut Pertanian Bogor Press.

Valentao, P. E., Fernandes, F., Carvallo, P. B., Andrade, R. M., Seabra, M. L. \& Bastos. (2001). Antioxidant activity of centaurum erythraea infusion evidenced by its superoxide radical scavenging and xanthine oxide inhibitory activity. Journal Agricultural Food Chemistry, 49(7), 3476-3479.

Wijaya, A. (1996). Radikal bebas dan parameter status antioksidan, forum diagnosticum. Prodia Diagnostic Educational Services, 1, 1-12.

Winarsi, H. (2007). Antioksidan alam dan radikal bebas. Yogyakarta: Kanisius. 